\title{
Development of the National Identity Measurement Using the Implicit Association Test Method
}

\author{
Christiany Suwartono \\ Faculty of Psychology \\ Atma Jaya Catholic University of Indonesia
}

\author{
Eko A. Meinarno and Gugah Bawono \\ Faculty of Psychology \\ University of Indonesia
}

This study is a first attempt to develop a new instrument using the Implicit Association Test (IAT) method. Researchers have tried to use this method in social psychology research, particularly to measure the construct of national identity. The national identity is a multidimensional construct and has several fundamental attributes, namely the same territorial, historical memories, culture, general rights laws and obligations for all members, and equal rights in the economic and territorial mobilization for group members. The study was conducted with 48 participants aged $17-23$ years $(M=18.98, S D=1.25)$. The result showed that the correlation between explicit and implicit measures on the construct of national identity was positive but not significant. Moreover, the explicit and implicit measurement did not provide the same pattern; indicating that both measurements measure national identity construct from a different point of view. Next, we evaluate the strengths and weaknesses of the two measurement methods in the Discussion section and then, provide recommendations for further studies.

Keywords: Implicit Association Test, self-report scale, implicit measurement, national identity, adolescence

\begin{abstract}
Penelitian ini merupakan upaya awal pengembangan alat ukur dengan metode Tes Asosiasi Implisit (Implicit Association Test.) Para peneliti mencoba penggunaan metode ini dalam penelitian psikologi sosial, khususnya pengukuran konstruk identitas nasional. Identitas nasional merupakan konstruk multi-dimensi dan memiliki beberapa atribut mendasar yaitu teritorial yang sama, kenangan-kenangan historis yang sama, budaya masyarakat umum yang sama, hak-hak akan hukum dan kewajiban bagi seluruh anggota yang sama dan hak yang sama dalam ekonomi dan mobilisasi teritorial bagi anggota kelompok. Penelitian dilakukan dengan 48 partisipan berusia antara 17-23 tahun $(M=18,98, S D=1,25)$. Hasilnya, korelasi antara pengukuran implisit dan eksplisit dalam mengukur konstruk identitas nasional menunjukkan hasil korelasi yang positif namun tidak signifikan. Kemudian, hasil dari kedua alat dengan dua metode ini ternyata tidak menampakkan pola yang sama. Hal ini menunjukkan bahwa kedua metode pengukuran ini mengukur identitas nasional dari sudut yang berbeda. Selanjutnya, kami melakukan evaluasi kemudian memaparkan kekuatan dan kelemahan kedua tipe alat ini dalam diskusi. Kemudian kami memberikan rekomendasi untuk penelitian serupa di masa mendatang.
\end{abstract}

Kata kunci: Tes Asosiasi Implisit, skala lapor diri, pengukuran implisit, identitas nasional, remaja

The measurement of attitude is typically carried out using a self-report method. Participants are asked to report their degree of agreement to the statements in the questionnaire. The questionnaire can be a paper and pencil survey or an online survey.

Correspondence concerning this article should be addressed to Christiany Suwartono, Faculty of Psychology Atma Jaya Catholic University of Indonesia, Jalan Jenderal Sudirman 51, Jakarta 12930, Indonesia. E-mail: christiany.suwartono@atmajaya.ac.id
Unfortunately, when the questionnaires are returned to researchers, sometimes the results are dubious. This is due to the answers given by participants; there were answers that always in the category of "strongly agree" or "very appropriate" and vice versa. This may indeed be the attitude of participants, but from our further interview, participants sometimes felt "compelled" to answer the questions. This is because they felt that they "should" respond in a certain 
way based on their knowledge of the purpose of measurement. However, Aronson, Wilson, and Akert (2006) found that sometimes participants did not realize their responses due to cognitive processes that underlie decision making in selecting responses. For example, in general, a person prefers to provide a positive quality of him(her)self rather than his(her) real self. The consciousness or unconsciousness of participants' conditions makes the measurement of a person's attitude toward an object face some challenges.

One of the challenges is the courage to declare the real stance, a desire to be regarded as a good person, even a desire to be considered as unfavorable by people around him/her. When the answers do not represent the attitude of oneself, then the person is said to commit a faking (Kelly \& Barnes-Holmes, 2015; Kemp, Miltenberger, \& Lumley, 1996). Uhlmann, Poehlman, and Nosek (2010) state that humans have two forms of thought processes, namely explicit and implicit, which in turn will form an attitude towards a particular object. Explicit attitudes can be construed as either positive or negative conscious evaluation of a particular object that can be easily accessed by someone. Whereas implicit attitudes are either positive or negative evaluation that can appear unconsciously, unwanted, and cannot be controlled (Aronson et al., 2006). Thus, a participant's written responses are the representation of the attitude that he/she realized and is readily available through his/her cognition at the time. Therefore, measurements using a self-report questionnaire sometimes cannot represent things that are perceived by participants.

Fazio, Jackson, Dunton, and Williams (1995, in Nurrachman \& Suwartono, 2011) found that the strength of relationship between attitude and strength of attitude can be obtained without asking participants to report this. The attitude of participants could be measured using a priming technique. It is assumed that people will take actions immediately toward objects (physical or social) according to the most prevailing associations with these objects in their minds.

Greenwald and Banaji (1995) state that an implicit attitude is the result of experiences that generate feelings, thoughts, or actions, related to both positive and negative outcomes with an object or a concept. They state that an implicit attitude is something that cannot be identified by individuals through introspection in the same way as in an explicit measure; that is, when individuals take a test. This is due to the method used in the implicit measurement where participants have only limited time to respond to a given stimulus.
Based on this, an implicit attitude is the result of automatic evaluation processes within individuals (Nosek, Greenwald, \& Banaji, 2007). It is often regarded as evaluative associations that are the result of experiences that affect a person's judgments and actions. An attitude is determined by its associations with an object or a concept, although a person is not necessarily aware of these associations (Uhlmann et al., 2010). To measure an attitude, researchers need to develop a special instrument using the Implicit Association Test (IAT) method. The IAT is a procedure used to mea-sure implicit and automatic associations (Greenwald, McGhee, \& Schwartz, 1998). The influence of implicit associations can be increased if an individual is in a state where (s)he cannot control his/her actions consciously (Uhlmann et al., 2010). Therefore, using IAT, individuals are given a brief time $(250 \mathrm{~ms})$ so that individuals have little control to their own actions. Using this method, we examined implicit attitudes or behaviors that automatically occur toward an object or a concept.

Implicit attitudes are independent evaluations that often unconsciously arise (Aronson et al., 2006; Taylor, Peplau, \& Sears, 2006). The gap found in the implicit process is often considered more natural and real than the response that appears on paper and pencil methods. The IAT is a technique to measure the strength of association between two concepts and attributes. The assumption underlying the IAT is that if target concepts and attributes are highly associated (congruent), then participants' reaction time toward the stimuli tends to be fast and precise. However, participants' responses will be slow and inaccurate if the target concepts and attributes of the concept have less association. This technique allows participants to have only limited time to think about "right or wrong" response. With the IAT, persons' limitations in showing implicit attitudes can be assessed. The assumption is that the faster the participants respond to stimuli, the more positive their national identity.

The association between a concept and an attribute is measured by calculating the required time differences (latency in millisecond units). For example, participants use the same response button for a target concept and a "good" attribute of the concept and use a different response button for a target concept and a "bad" attribute of the concept (Smith \& Nosek, 2012). The time span required by participants to respond to the appearance of a stimulus in the center of a computer screen is the latency measured in the IAT. For example, in Figure 1, a participant will see a word "NYAMAN" (comfortable) in 


\begin{tabular}{|lr|}
\hline $\begin{array}{l}\text { Menyenangkan } \\
\text { Pleasant }\end{array}$ & Tidak Menyenangkan \\
Unpleasant
\end{tabular}

Figure 1. An example of IAT.

the middle of a computer screen. The participant should hit " $E$ " on the computer keyboard if (s)he considers that the word "nyaman" (comfortable) belongs to "Menyenangkan" (pleasant) category. However, if the participant think that the word "NYAMAN" (comfortable) belongs to "Tidak Menyenangkan" (unpleasant) category, then (s)he should hit the "I" key on the computer keyboard.

Indonesia has a potential to be a great nation since it has very rich natural and human resources. Indonesia's total population has increased in 10 years; from 205.1 million in 2000 to 237.6 million in 2010 (Badan Pusat Statistik Indonesia, 2012). Moreover, as the largest archipelago country in the world, Indonesia consists of 300 ethnic groups with approximately 700 regional languages (Badan Pusat Statistik Indonesia, 2009). Nevertheless, to be a great nation, it requires solid human resources that are aware of their national affiliation and show support for the unity in diversity. Therefore, the process of establishing a national identity of Indonesia is not yet ended.

Turner (1984) states that national identity is one form of social identity that needs to be explored, he even asserts that national identity is an attractive area of study. National identity is defined as a type of social identity that stems from the feeling of belonging to and identification with a particular nation (Mavric, 2014). Positive social identity provides a sense of security, self-esteem, self-worth, and affiliation (Mavric, 2014). National identity is not only an interesting issue for scientific studies but also for general public and political affairs.

The current study investigated the issue of national identity among adolescents, as they are potentially to be the nation's future leader. According to Erikson, adolescents develop a concept of "solidarity with the group that (s)he thinks ideal" (Erikson, 1968 in Vedder and Phinney, 2014). An ideal group is not only peer groups but also groups based on ethnicity, religion, residence, or even a combination of the group characteristics. If it is drawn to a larger group, it could be a country. Consequently, the aim of this study was to examine whether the national identity of adolescents as explicitly measured by a self-report scale is aligned with those implicitly measured using the Implicit Association Test.

In the current study, the explicit and implicit measurements were carried out with the theme of national identity. This is the first attempt in Indonesia to examine the potential use of IAT for investigating national identity. The IAT consists of sorting tasks that require participants to sort stimuli based on two concepts (representing Indonesia and Thailand) or attributes (good vs. bad) using two response options (hitting "E" for left response key or "I" for right response key). The logic behind the IAT is that the sorting tasks will be correctly responded in a shorter period of time if the two concepts in combination with certain attributes are strongly associated in contrast to weakly associated concepts and attributes (Nosek, Greenwald, \& Banaji, 2007). For example, if a person has a high level of national identity for Indonesia, s/he will respond correctly to Indonesia's "target" stimuli with good "attribute" in a shorter response time compared to Thailand's "target" stimuli with good "attribute".

For an explicit measurement, we used the reformlated Collective Self-Esteem Scale (Lilli \& Diehl, 1999). We tested if the IAT and self-report were in alignment and measured related but distinct constructs. Both methods were used to reveal a degree of national identity in less visible and immediate way. For consistency of the results, the use of IAT to measure national identity (Inas IDN IAT) was followed by an explicit measurement of national identity using a national identity questionnaire.

\section{Method}

\section{Participants}

Of 48 participants who participated in this survey, $75 \%$ were females, and $25 \%$ were males. The youngest participants was 17 years old while the oldest participants was 23 years old $(M=18.98, S D=$ 1.25). Most participants were Muslims (62.50\%), followed by Catholics (20.83\%), Protestants (10.42\%), Hindus $(2.08 \%)$, Buddhists $(2.08 \%)$, and the remaining did not answer the question about religion. All of the participants were senior high school graduates, $54.17 \%$ attended public schools. The ethnicities of the participants were mostly Javanese (35.40\%). Others were Tionghoa (12.50\%), Sundanese (8.3\%), 
Bataknese (6.3\%), and other ethnicities. Notably, only data from 33 participants could be further processed because 15 participants did not fill out the reformulated Collective Self-Esteem Scale.

\section{Research Instruments}

Explicit measures. The national identity scale was adapted from the Collective Self-Esteem Scale (Luthanen \& Crocker, 1992). This adaptation called reformulated Collective Self-Esteem Scale (Lilli \& Diehl, 1999) consists of 20 items measuring the level of identification of a person against a country. Lilli and Diehl substituted "group" by "nation" in all necessary statements. The examples of the item are "I am a worthy member of Indonesia", "I feel good about Indonesia", and "Indonesia, the nation that I belong to is an important reflection of who I am".

In each item statement, participants were asked to choose one of the options ranging from very appropriate to very inappropriate. The reliability coefficient in this study was $.92(M=85.36 ; S D=12.36)$. Participants were also asked to complete demographic data, such as age, gender, religion, ethnicity and the level of pride to be an Indonesian. For the last question, participants were asked to choose a number from one to ten, where one indicates not proud at all and ten indicates very proud.

Implicit Measures. The Implicit Association Test (IAT) is a procedure used to measure implicit and automatic associations (Greenwald et al., 1998). The influence of implicit associations can be increased if an individual is in a state where s/he cannot control his/her actions (Uhlmann, Poehlman, \& Nosek, 2010). Therefore, when conducting the IAT, individuals are given only limited time so that $\mathrm{s} / \mathrm{he}$ has a minimal control over his/her actions. This measurement method is used to examine implicit atti- tudes or attitudes that occur automatically toward objects or concepts.

The Indonesian Implicit National Identity Test (Inas IDN IAT) is a computer-based measurement that applies the IAT procedures. The Inas IDN IAT can be run by the Inquisit 2.0.60616 program launched by Millisecond Software in 2011. The Inquisit 3 program provides seven different experimental scripts which can be changed or designed according to the user's needs. The seven types of scripts are Simplified Implicit Attitude Task, Standard IAT, Demographic Survey, Standard Picture IAT, Subliminal Priming Task, Covert Attention Task, and Dot Probe Task (Millisecond Software, 2011).

The Inas IDN IAT used the Standard IAT script consisting of seven blocks and the type of stimulus shown was in the form of pictures and words. Each block consisted of 20 trials, except for the fourth and seventh blocks that comprised 40 trials. The outline design of Inas IDN IAT can be seen in Table 1.

In the first block, participants were instructed to hit ' $E$ ' when they saw a picture representing Indonesia and hit 'I' when they saw a picture representing Thailand. In the second block, participants should hit 'E' when they saw a "Good" term such as "Friendly", or to hit 'I' when they saw a "Bad" term such as "Evil". The third block was a combination of the first and second blocks. The third block was intended as a practice session. The fourth block was the same as the third block. The fifth stage was the opposite of the first stage. The sixth and seventh stages were similar to the third and fourth stages but the target stimulus discrimination were reversed. The fifth blocks until the seventh blocks were meant to counterbalance the order of combined blocks between targets. Thus, both target stimuli, whether Indonesia or Thailand had an equal chance to be paired with good or bad attributes.

Table 1

The Design of the Indonesian Implicit National Identity Test

\begin{tabular}{|c|c|c|c|c|}
\hline \multirow[b]{2}{*}{$\begin{array}{l}\text { Block } \\
\text { No. }\end{array}$} & \multirow{2}{*}{$\begin{array}{l}\text { Number } \\
\text { of } \\
\text { Stimuli }\end{array}$} & \multirow[b]{2}{*}{ Task } & \multicolumn{2}{|c|}{ Response Key Task } \\
\hline & & & $\begin{array}{l}\text { Left Response Key } \\
\text { ("E") }\end{array}$ & $\begin{array}{l}\text { Right Response Key } \\
\text { ("I") }\end{array}$ \\
\hline 1 & 20 & Target discrimination & Indonesia & Thailand \\
\hline 2 & 20 & Attribute discrimination & Positive words (Good) & Negative words (Bad) \\
\hline 3 & 20 & The combined task (initial) - practice & Indonesia, positive words & Thailand, negative words \\
\hline 4 & 40 & The combined task (initial) & Indonesia, positive words & Thailand, negative words \\
\hline 5 & 20 & Target discrimination (reversed) & Thailand & Indonesia \\
\hline 6 & 20 & $\begin{array}{l}\text { The combined task (reversed) - } \\
\text { practice }\end{array}$ & Thailand, positive words & Indonesia, negative words \\
\hline 7 & 40 & The combined task (reversed) & Thailand, positive words & Indonesia, negative words \\
\hline
\end{tabular}



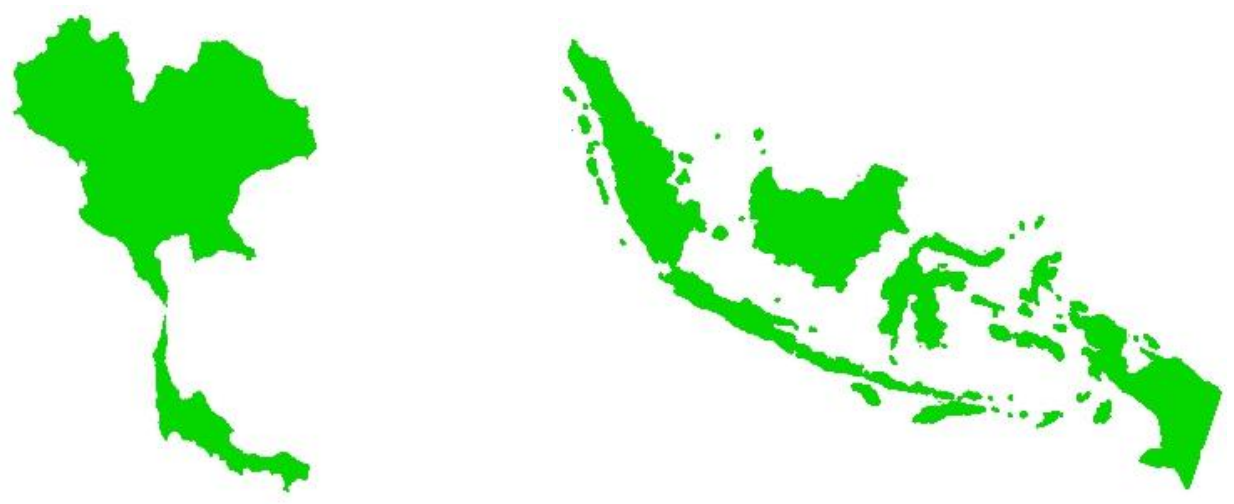

Figure 2. The example of a target concept stimulus in The Indonesian Implicit National Identity Test.

Table 2

The Attributes Stimuli of the Indonesian Implicit National Identity Test

\begin{tabular}{lcccc}
\hline \multicolumn{1}{c}{$\begin{array}{c}\text { Attributes } \\
\text { Stimuli }\end{array}$} & $\begin{array}{c}\text { Proportion of } \\
\text { Correct } \\
\text { Answers }\end{array}$ & $\begin{array}{c}\text { Minimum } \\
\text { Reaction Time } \\
(\mathrm{ms})\end{array}$ & $\begin{array}{c}\text { Maximum } \\
\text { Reaction Time } \\
(\mathrm{ms})\end{array}$ & $\begin{array}{c}\text { Mean Reaction } \\
\text { Time } \\
(\mathrm{ms})\end{array}$ \\
\hline Bahagia (Happy) & 100 & 376 & 814 & 554.7 \\
Baik (Good) & 100 & 419 & 1361 & 635.89 \\
Berani (Brave) & 70 & 531 & 4162 & 1477.6 \\
Puas (Satisfy) & 100 & 512 & 780 & 614.5 \\
Ramah (Friendly) & 100 & 472 & 1249 & 730.4 \\
Sukses (Success) & 100 & 478 & 1136 & 659 \\
Tenang (Calm) & 91 & 453 & 2335 & 831.09 \\
Toleran (Tolerant) & 100 & 468 & 1846 & 779 \\
Benci (Hate) & 100 & 380 & 1216 & 649 \\
Bosan (Bored) & 82 & 425 & 4412 & 1112 \\
Buruk (Bad) & 100 & 432 & 300 & 574.82 \\
Jahat (Evil) & 88 & 491 & 1733 & 984.63 \\
Jelek (Ugly) & 100 & 437 & 2311 & 828.78 \\
Licik (Cunning) & 100 & 360 & 798 & 795.27 \\
Munafik (Hypocrite) & 100 & 492 & 2290 & 599.8 \\
Pengecut (Coward) & 100 & 509 & & 851.11 \\
\hline
\end{tabular}

Participants' task was to categorize each stimulus that appears in the center of a computer screen into four predefined categories. In the Inas IDN IAT, the four categories were divided into two groups, the target and attribute categories. The target categories consisted of "Indonesia" and "Thailand". The stimu$\mathrm{li}$ in this category represented "Indonesia" and "Thailand", including images of flags, state symbols, territories, arts, and currencies used in Figure 2 shows the examples of pictures of the target stimuli of the Inas IDN IAT.

Each country was represented by eight stimuli shown in Appendix. The category of attributes con- sisted of "Positive Words" (e.g. friendly, good) and "Negative Words" (e.g. bad, bad). Each category consists of eight stimuli shown in Table 2. The computer measured participants' reaction times which then inputted into an algorithm to generate $\mathrm{D}$-score.

\section{Procedure}

Preparation. The authors conducted stimulus elicitation activities in advance to identify target categories and accelerate stimulus attributes accessible to consciousness that would be used by participants to categorize the stimuli into "Indonesia", 
"Thailand", "Positive Words" and "Negative Words". For "Indonesia" and "Thailand" representations, we used stimulus images from Google Image sites and conducted some modifications (cropping, image coloring, and rotating). Next, we did a pilot study to test the stimuli.

We conducted a pilot study to ensure that all stimuli were easy to recognize and participants was easy to differentiate the categories. For the pilot study, we asked eight students to perform the categorization tasks. The results of target stimuli are in Appendix.

The Inquisit program recorded participants' response time when conducting the stimulus categorization. The participants' response time and their correct or incorrect answers were expected to have no latency greater than $10,000 \mathrm{~ms}$ and lesser than $300 \mathrm{~ms}$. The accepted responses are participants' correct answers within the time range of 300-3000 ms (Teige-Mocigemba, Klauer, \& Sherman, 2010). Sixteen images were used in the Inas IDN IAT. The participants in the pilot study could discriminate the images that belong to either Indonesia or Thailand correctly and quickly $(M<3,000 \mathrm{~ms})$.

The participants were also asked to perform discrimination tasks with the attribute stimuli. The results of the attribute stimuli are shown in Table 2.

The participants in the pilot study could discriminate the words that belong to either positive or negative attribute correctly, and the mean reaction time for each stimulus was under $3,000 \mathrm{~ms}$.

The next step, we developed a script for the Inas IDN IAT to measure the implicit aspects of national identity by integrating the target and attribute stimuli in the Inquisit. We built the Inas IDN IAT based on our design as seen in Table 1.

The sense of belonging to a group (nation) and social identification can occur only when compared with a group that they do not belong to (Mavric, 2014). This directed our decision to use the Standard IAT, based on two concepts. Participants were given stimuli that compared the two concepts, namely Indonesia and other country (in this case, Thailand). We selected Thailand based on several reasons. Thai is a group of ethnic majority, and as a consequence, Thailand is the country's Thai nation (nation-state; Thananithichot, 2011). We chose Thailand as a comparison country for Indonesia in the IAT because there is no history of conflict between Indonesia and Thailand; thus, Indonesians' attitude toward Thailand is arguably considered as neutral. Both countries were represented in the IAT in the form of states (republican-royal), geography of the country (the island-mainland Asia), cultures (heterogeneous-almost homogeneous), and symbols of the country (such as money, state emblems, and flags).

After all preparations were set up; that is, making decisions on the target and attribute stimuli, we designed the Inas IDN IAT consisting of seven blocks that could be done individually by participants. In general, the participants were asked to categorize the stimuli. The stimuli appeared on the monitor for each block; participants should respond to the stimuli that belong to the left-side category by pressing the ' $E$ ' letter on the computer keyboard and to the stimuli that belong to the right-side category by pressing the 'I' letter. Figure 3 ( $a$ and $b$ ) show an example of the task.

Data collection. Data were collected in two places, at the Atma Jaya Catholic University of Indonesia and University of Indonesia. The participants came to the computer lab and faced a computer. The Indonesian Implicit National Identity Test (Inas IDN IAT) was administered on laptops and personal computers with Inquisit 2.0.60616 program. The participants were asked to respond to any stimuli that appear on the computer screen in a relatively short time. Usually, it took about 20 minutes for participants to complete all seven sessions. At the end of administration, a Dscore appeared. Participants wrote the D-score in the questionnaire and completed the rest of the questionnaire. We used test-retest reliability method to test the Inas IDN IAT reliability, the participants were required to return to the computer lab a week later.

Analysis. The calculation for the IAT was based on the calculation of a D-score. The scoring method was based on an article by Greenwald, Nosek, and Banaji (2003). The D-IAT score can be computed directly by the Inquisit that run the Inas IDN IAT (the program can be downloaded from https://www. millisecond.com/). There are several steps to calculate the D-IAT Score. First, the average latency is computed for all four blocks of focus: blocks 3, 4, 6 , and 7 . Thus, there are four average score obtained because the four blocks are counted. Then, the combined standard deviations of latency in the third and the sixth blocks, as well as in the fourth and seventh blocks are computed. Thus, we have two standard deviations of $S D_{3-6}$ and $S D_{4-7}$. Next, a "da" (see DIAT scoring visualization scheme) is computed by subtracting the mean latency of the sixth block from the average latency of the third block, and then the result of subtraction is divided by the combined standard deviation of latency of the third and sixth blocks $\left(S D_{3-6}\right) . \mathrm{A}$ "db" is calculated in the same way, by subtracting the mean latency of the seventh block by 


Indonesia
atau or
Baik
Good
Lihat di atas layar monitor Anda, empat kategori yang Anda lihat secara terpisah sekarang muncul
bersamaan. Ingat, setiap stimulus hanya tergolong pada satu kelompok. Misalnya, jika kategori bunga dan
Baik muncul di sisi yang terpisah pada layar di atas. Maka gambar bunga akan pergi dalam kategori bunga,
bukan kategori Baik.
See above, the four categories you saw separately now appear together. Remember, each item belongs to only one group.
For example, if the categories Flower and Good appeared on separate sides above, then Flower would go in the Flower
category, not the Good category.
Warna label hijau dan putih dan stimulus dapat membantu untuk mengidentifikasi kategori yang sesuai.
Gunakan tombol E dan I untuk mengkategorikan stimulus ke dalam kelompok kiri dan kanan, dan perbaikilah
kesalahan dengan menekan tombol huruf lain.
The green and white labels and items may help to identify the appropriate category. Use the E and I keys to categorize items
into four groups left and right, and correct errors by hitting the other key.
Tekan TOMBOL SPASI untuk memulai
Press the SPACE BAR to begin

Figure $3 a$. The example of block three.

\footnotetext{
Thailand

atau or

Indonesia

Baik

Good

Lihat di atas layar monitor Anda, empat kategori sekarang muncul bersama dalam sebuah konfigurasi baru. Ingat, setiap item milik hanya satu kelompok.

See above, the four categories now appear together in a new configuration. Remember, each item belongs to only one group.

Label warna hijau dan putih dan stimulus dapat membantu untuk mengidentifikasi kategori yang sesuai. Gunakan tombol E dan I untuk mengkategorikan stimulus ke dalam empat kelompok kiri dan kanan, dan memperbaiki kesalahan dengan menekan tombol lain.

The green and white labels and items may help to identify the appropriate category. Use the E and I keys to categorize items into the four groups left and right, and correct errors by hitting the other key.
} atau or

Tekan TOMBOL SPASI untuk memulai Press the SPACE BAR to begin

Figure $3 b$. The example of block six.

the average latency of the fourth block; and then the result is divided by the combined standard deviation of latency of the fourth and seventh blocks $\left(S D_{4-7}\right)$. Finally, a D-IAT score is calculated from the mean "da" and "db" (the sum of "da" and "db" divided by two).
The more positive D-IAT means that participants have a higher belonging to and identification with Indonesia. Conversely, the more negative D-IAT means that participants have a lesser degree of belonging to and identification with Indonesia. Figure 4 is a visual calculation to obtain a D-IAT score. 
The D-IAT score (D-score) symbolizes the implicit measurement of national identity. This method is used to reveal a degree of national identity from the strength of the associations between Indonesia and positive words.

The scores of implicit and explicit measures of national identity were then converted to Z-scores, and we used Pearson's product-moment correlation to test the relationship between the implicit and explicit measurement. We also tested the relationships between the implicit and explicit measures and the pride level being an Indonesian using Pearson's product-moment correlation.

\section{Results}

For reliability testing of the measures, we used test retest method; that is, the time between the first and second administration of the questionnaire. The first measurement resulted a $\mathrm{D}$-score ranging from - 0.28 to $1.09(M=0.46, S D=0.32)$, whereas the second measurement produced a $\mathrm{D}$-score ranging from - 0.15 to $1.13(M=0.51, S D=0.31)$. The time span between the first and second administration was one week. As a result, there was a significant relationship between the first and second test with $r_{(46)}=$ $.35, p<.05$ (two-tailed). The Inas IDN IAT was reliable. Additionally, it was found that there was no significant difference between the first and second administration with $t_{(47)}=.86, p>.05$ (twotailed). There was no effect of familiarity.

From data collection, we converted the scores to $\mathrm{Z}$-scores and had the pattern of relationships between the implicit and explicit measurement of national identity. In particular, the results of the two measurements did not provide the same trend (see Figure 5).

The correlation between implicit and explicit measurement was $r_{(31)}=.05, p>.05$ (two-tailed). The result suggests that there was no relationship between implicit and explicit measurement of the construct of national identity. The power of positive associations with Indonesia was not associated with a

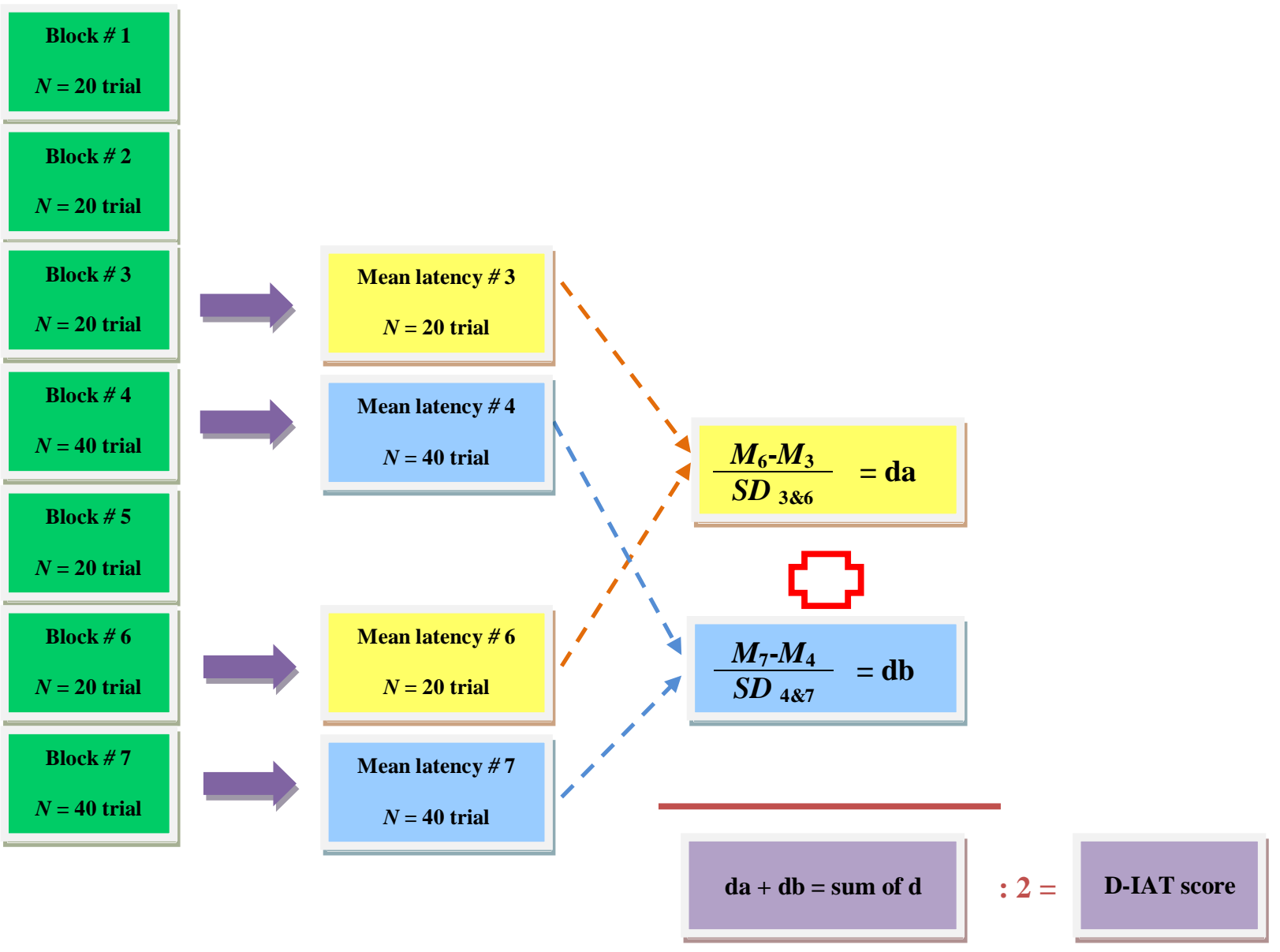

Figure 4. The visualization scheme of D-IAT score calculation. 


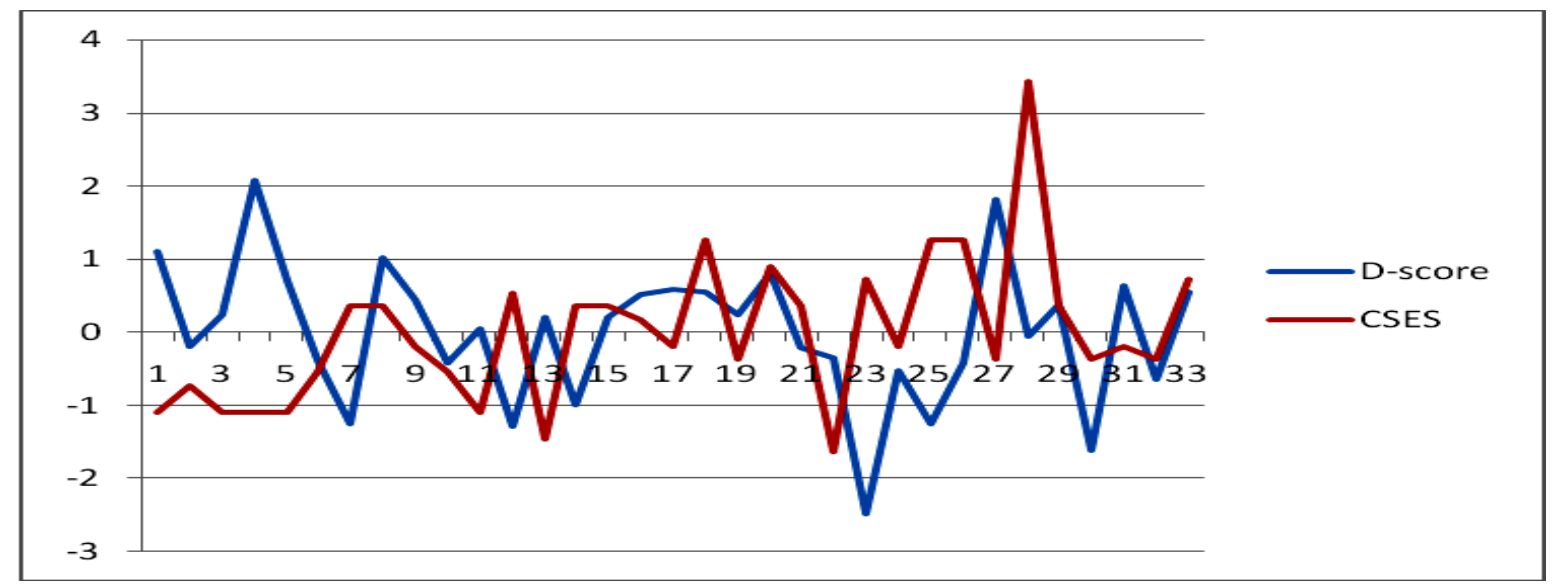

Figure 5. The response patterns of the implicit versus explicit measures of national identity construct.

valuable sense of oneself as a part of Indonesia.

The correlation between the implicit measure and the pride level to be an Indonesian was $r(46)=-.34$, $p<.05$ (two-tailed). This indicates that the lower positive associations with Indonesia, the higher the level of pride as an Indonesian. On the other hand, the higher positive associations with Indonesia, the lower the level of pride to be an Indonesian.

The correlation between the explicit measure and the pride level to be an Indonesian was $r(46)=-.03$, $p>.05$ (two-tailed). There was no significant relationship between the explicit measure and the level of pride to be an Indonesian.

\section{Discussion}

A self-report or a paper and pencil test can capture people's cognitive and mental processes that are often not realized or seized by the test (Aronson et al., 2006). The Indonesian Implicit National Identity Test (Inas IDN IAT)'s development had the same results with previous research (Greenwald et al., 1998; Hartono \& Suwartono, 2012; Hoffman, Gawronski, Gscwendner, Le, \& Schmitt, 2005; Wicaksana \& Suwartono, 2012). The Inas IDN IAT had a weak but significant correlation in test-retest reliability. Considering that this is the first attempt to develop an implicit measure of national identity, we conclude that the result is promising. We have also had pictures and attributes of stimuli that participants could discriminate instantly into proper categories. However, further study is needed to evaluate the testretest reliability of the Inas IDN IAT.
The correlation between the Inas IDN IAT as an implicit measure and the reformulated Collective Self-Esteem Scale as an explicit measure was a weak and not significant. This means that the IAT and self-report assess a related but a distinct construct. The difference between the two measures lies in the process of response generated and what is measured. The Inas IDN IAT measures national identity implicitly, relating this to cognitive assessment performed by oneself which is activated by participants' responses to given stimulus and represents the strength of association with what one feels about Indonesia, whilst an explicit self-report scale is considered as the result of mind reflection and consciousness in evaluating of oneself as an Indonesian. However, the result could also be attributed to the small sample size. Further research should take a larger sample size to test the psychometric properties of the Inas IDN IAT. The absence of a significant correlation between the implicit and explicit measures can also be due to the IAT emphasizes the speed of response of participants. Thus, participants' main concern was only on processing time to complete the IAT. The IAT is expected to reveal something that exists in the unconsciousness, but the questionnaire requires a deeper introspection process so that the response can describe oneself. The non-significant relationship between these measurements was revealed in the pattern of responses of the implicit versus explicit measure of national identity construct. In this study, the Inas IDN IAT was not very efficient in exposing the issue of national identity. Another explanation could be related to the implicit measurement which measured the power of associations with Indonesia. 
The stimuli used in this study were the formal state symbols of Indonesia. The non-significant relationship between the measurements might be due to the implicit target of macro elements of human behavior, while the explicit measurement was more focused on the micro elements of human behavior.

The negative but significant correlation between the implicit measure and the level of pride of a person to be an Indonesian raises a question: is it true that higher positive associations with Indonesia indicate that a person does not wish to or expresses his or her pride to be an Indonesian? Referring to the social identity theory by Tajfel (1982), an individual tends to adjust his or her pride in accordance to his or her in-group, and his or her self-concept depends on the in-group's evaluation toward the out-group. Thus, participants in this study might feel that the larger group (Indonesians) was no better than the other group (people of Thailand). Participants' self-evaluation regarding Indonesia was not better than their evaluation regarding Thailand. Based on this point of view, it is concluded that participants' self-identification in relation to national identity is weak. This indicates that national identity that we expected to grow did not appear even though Indonesia has gained independence since 1945. It has not yet become an awareness that can be carried into un-awareness. The national identity as Indonesians might be considered less favorable, at least, among participants in this study.

Although we have tried to standardize the national identity constructs in the Inas IDN IAT, such as the emblem and symbol of the state, this is not sufficient. The pictures that represent Thailand (such as dance and places of worship) seem to represent only the majority of ethnic groups in Thailand. In contrast, the pictures that represent Indonesia might be more representative of Indonesian diverse groups. For example, the picture of places of worship did not represent the religion of the majority people (Islam). Additionally, the picture of dancers illustrated Balinese culture. Balinese is not the ethnic majority. It could be that the participants did not see the relevance between Balinese dance and their larger group identity (national identity). Indonesia is also a multi-ethnic society, with more than 300 ethnic groups. However, the sizes of most ethnic groups are small, and only 15 groups have more than one million each (Suryadinata, Arifin, \& Ananta, 2003). The participants seemed to be able to express their level of identification with Indonesia on the explicit measurement.

The reformulated Collective Self-Esteem Scale consists of five domains (Lilli \& Diehl, 1999), namely membership (a person's worth for or contribution to the in-group), private (a person's view of the in-group's value), public (other persons' view of this group), identity (contribution of ingroupmembership to the self-concept of the individual), and comparison (a person's view of outgroups compare to in-group). These factors do not seem to be parallel to the target concept's pictures and attributes in the IAT. In relation to the membership factor, for example, the Inas IDN IAT might not include pictures in participant's category that could boost their sense of pride as a part of a nation. In contrast, it is easier to include this factor in the explicit measure. It is possible that participants have an ideal condition; and therefore, the explicit measurement can represent the membership factor in order to capture the national identity construct, whereas the implicit method has failed to capture this. This condition may also occur in other domains where the initial design is not in harmony with the measurement of Inas IDN IAT.

\section{Limitations and Future Directions}

There are several limitations that should be considered. First, regarding the pictures of target stimuli of the Inas IDN IAT, the main challenge is to have representative pictures for the stimuli that represent Indonesia, the pictures should be familiarized by Indonesians, and participants should be able discriminate the target quickly. One of the target stimuli, the currency, should be further examined if it will be included in the future Inas IDN IAT. Second, our current sample size is limited. Further research should include a larger sample size and reach people from a wider geography area and age range. Third, there is a need to conduct a validation study of the Inas IDN IAT. Future research can use the Multitrait-Multimethod to validate the Inas IDN IAT and include other measurements such as the Single-Target Implicit Association Test (ST-IAT; cf. Nosek \& Smyth, 2007) for an implicit measure and use explicit measures assessing various psychological constructs related to national identity.

\section{Conclusion}

Overall, the results obtained from this prelimnary study provide a foundation for measuring national identity using the implicit association test method. The Inas IDN IAT can provide a measurement of implicit attitudes, revealing the most dominant associa- 
tions in a person's minds. Therefore, it can be used to investigate a degree of national identity in less visible and immediate way.

\section{References}

Aronson, E., Wilson, T. D., \& Akert, R. M. (2006). Social psychology (6th ed). New Jersey: Pearson Prentice Hall.

Badan Pusat Statistik Indonesia. (2009). Data demografik Indonesia 2008 [Indonesian demographic data 2008]. Retrieved from http://www.bps.go.id.

Badan Pusat Statistik Indonesia. (2012). Perkembangan beberapa indikator utama sosial-ekonomi Indonesia [Trends of selected socio-economic indicators of Indonesia]. Retrieved from http://www.bps.go.id/ booklet/Booklet_Agustus_2012.pdf

Greenwald, A. G., Nosek, B. A., \& Banaji, M. R. (2003). Understanding and using the Implicit Association Test: I. An improved scoring algorithm. Journal of Personality and Social Psychology, 85(2), 197-216.

Greenwald, A. G., \& Banaji, M. R. (1995). Implicit social cognition: Attitudes, self-esteem, and stereotypes. Psychological Review, 102, 4- 27.

Greenwald, A. G., McGhee, D. E., \& Schwartz, J. L. K. (1998). Measuring individual differences in implicit cognition: The Implicit Asociation Test. Journal of Personality and Social Psychology, 74, 1464-1480.

Hartono, A., \& Suwartono, C. (2012). Pengukuran self-esteem dengan metode self report dan Implicit Association Test. Jurnal Pengukuran Psikologi dan Pendidikan Indonesia, 2(2), 98-110.

Hoffman, W., Gawronski, B., Gscwendner, T., Le, H., \& Schmitt, M. (2005). A meta-analysis on the correlation between the Implicit Association Test and Explicit Self-Report Measures. Personality and Social Psychology Bulletin, 31(10), 1369-85.

Kelly, M. E., \& Barnes-Holmes, D. (2015). Measuring implicit and explicit acceptability of reinforcement versus punishment interventions with teachers working in ABA versus mainstream schools. The Psychological Record, 65(2), 251-265.

Kemp, F. D., Miltenberger, R. G., \& Lumley, V. A. (1996). Treatment acceptability and "faking good": Are staff telling us what they think we want to hear? Behavioral Interventions, 11, 181-191.

Lilli, W., \& Diehl, M. (1999). Measuring National Identity, Working Paper, Nr. 10, Mannheimer Zentrum für Europäische Sozialforschung. Retrieved from http://www.mzes.uni-mannheim.de/publica tions/wp/wp-10.pdf

Luthanen, R., \& Crocker, J. A. (1992). Collective self-esteem scale: Self-evaluation of one's social identity. Personality and Social Psychology Bulletin, 18(3), 302-318.

Inquisit 2.0.60616 [Computer software]. (2006). Seattle, WA: Millisecond Software.

Mavric, B. (2014). Psycho-social conception of national identity and collective self-esteem. Epiphany, $7(1), 184-200$.

Millisecond Software. (2011). "Inquisit tutorial". Retrieved from www.millisecond. com.

Nurrachman, N., \& Suwartono, C. (2011). Gambaran identitas nasional generasi muda Indonesia melalui Implicit Association Theory, (Unpublished Research Proposal). Atma Jaya Catholic University of Indonesia

Nosek, B. A., Greenwald, A. G., Banaji, M. R. (2007). The Implicit Association Test at age 7: A methodological and conceptual review (265-292). In J. A. Barg (Ed.), Automatic processes in social thinking and behavior (pp. 265-292). New York: Psychology Press.

Smith, C. T., \& Nosek, B. A. (2012). Implicit Association Test. Retrieved from http://projectimplicit .net.nosek/

Suryadinata, L., Arifin, E. N., \& Ananta, A. (2003). Indonesia's population: Ethnicity and religion in a changing political landscape. Singapore: Institute of Southeast Asian Studies.

Teige-Mocigemba, S., Klauer, K. C., \& Sherman, J. W. (2010). A practical guide to Implicit Association Test and related tasks. In B. Gawronski and B. K. Payne (Eds.), Handbook of implicit social cognition (pp.117-139) NY: Guilford Press.

Tajfel, H. (1982). Social psychology of intergroup relations. Annual Review of Psychology, 33, 1-59.

Thananithichot, S. (2011). Understanding Thai nationalism and ethnic identity. Journal of Asian and African Studies, 46(3), 250-263.

Turner, J. C. (1984). Social identification and psychological group formation. In H. Tajfel, The social dimension: European Developments in Social Psychology (Vol. 2, pp.518-538). Cambridge: Cambridge University Press.

Taylor, S. E., Peplau, L. A., \& Sears, D. O. (2006). Social psychology (12th Ed). Upper Saddle River, NJ: Prentice-Hall.

Uhlmann, E. L., Poehlman, T. A., \& Nosek, B. A. (2010). Automatic associations: Personal attitudes or cultural knowledge? United Kingdom: Oxford University Press. Wicaksana, D. \& Suwartono, C. (2012). Uji validi- 
tas dan reliabilitas alat ukur Indonesia Implicit Self Esteem Test (IISeT). Jurnal Pengukuran Psikologi dan Pendidikan Indonesia, 1(4), 297-321. Vedder, P., \& Phinney, J. S. (2014). Identity forma- tion in bicultural youth: A developmental perspective. In V. Benet-Martinez \& Y. Y. Hong (Eds), The Oxford handbook of multicultural identity (pp. 335354). New York: Oxford University Press. 


\section{Appendix}

The Pictures of Stimuli in the Indonesian Implicit National Identity Test

\begin{tabular}{|c|c|c|c|c|}
\hline $\begin{array}{c}\text { Target } \\
\text { Stimuli }\end{array}$ & $\begin{array}{c}\text { Proportion of } \\
\text { Correct Answers }\end{array}$ & $\begin{array}{c}\text { Minimum } \\
\text { Reaction Time } \\
(\mathrm{ms})\end{array}$ & $\begin{array}{c}\text { Maximum } \\
\text { Reaction Time } \\
(\mathrm{ms})\end{array}$ & $\begin{array}{c}\text { Mean } \\
\text { Reaction Time } \\
(\mathrm{ms})\end{array}$ \\
\hline & 100 & 443 & 3623 & 945.25 \\
\hline & 100 & 481 & 934 & 659.64 \\
\hline & 100 & 535 & 1140 & 820 \\
\hline & 80 & 610 & 1637 & 958.7 \\
\hline & 100 & 598 & 1407 & 871.78 \\
\hline & 89 & 555 & 3019 & 1369.56 \\
\hline & 100 & 548 & 2564 & 932.2 \\
\hline & 100 & 583 & 1319 & 768.89 \\
\hline & 100 & 569 & 1209 & 807.22 \\
\hline & 89 & 590 & 6893 & 1586.44 \\
\hline
\end{tabular}




\begin{tabular}{|c|c|c|c|c|}
\hline $\begin{array}{l}\text { Target } \\
\text { Stimuli }\end{array}$ & $\begin{array}{c}\text { Proportion of } \\
\text { Correct Answers }\end{array}$ & $\begin{array}{c}\text { Minimum } \\
\text { Reaction Time } \\
(\mathrm{ms})\end{array}$ & $\begin{array}{c}\text { Maximum } \\
\text { Reaction Time } \\
(\mathrm{ms})\end{array}$ & $\begin{array}{c}\text { Mean } \\
\text { Reaction Time } \\
(\mathrm{ms})\end{array}$ \\
\hline & 100 & 571 & 2157 & 1120.1 \\
\hline & 100 & 604 & 2830 & 1446 \\
\hline & 100 & 528 & 1055 & 764.62 \\
\hline & 56 & 704 & 3521 & 1795.44 \\
\hline & 78 & 741 & 6905 & 1687.11 \\
\hline & 100 & 612 & 1953 & 960.78 \\
\hline
\end{tabular}

Note. Proportion of correct answers was calculated as the frequency of participants successfully categorizing image stimuli according to the country in which they represent correctly compared to all participants in percentages. 